\title{
A Study On Effect Of Sleep Duration On Spo2 And Pulse Rate In College Students Of Angamaly, Kerala
}

\author{
Kumar Sai Sailesh ${ }^{1}$, Padmanabha ${ }^{2}$, Jobby Abraham $^{3}$, Jose Angel ${ }^{4}{ }^{\text {Mukkadan } \text { J.K }^{5}}$ \\ ${ }^{1}$ Research scholar, Little Flower Medical Research Centre, Angamaly \\ ${ }^{2}$ Asst.professor, Jazan University, Saudi Arabia \\ ${ }^{3}$ Vice Principal \& Professor, Travancore Medical College, Kollam. \\ ${ }^{4}$ Lecturer, Dept of Physiology, LIMSAR, Angamaly. \\ ${ }^{5}$ Research Director, Little Flower Medical Research Centre, Angamaly
}

\section{Abstract}

The present study was undertaken with an objective to observe the effect of sleep duration on spo 2 and pulse rate in males and females and to create awareness among the general population to improve the quality of life. The present study has been performed at Little Flower Medical Research Centre, Angamaly, Kerala, India. A total of two hundred and twenty two healthy male and female college students, with mean age $18.55 \pm 0.94$ were participated voluntarily in the medical camp comprising 110 males and 112 females. Two investigators of our study recorded Spo 2 and pulse rate by using pulse oximeter from the students at the same time. The participants were grouped into two groups, those who sleep more than seven hours and those who sleep for less than seven hours and their spo 2 pulse rate were compared. The analysis of data was done by SPSS 20.0. Independent sample $t$ test is used for data analysis. Spo2 is equal in both the groups. However pulse rate is slightly lower in the students who sleep less than seven hours. However this is not statistically significant (P value 0.372 ). Our study suggests that Pulse rate is slightly lower in the students whose sleep duration is less. No significant change is observed in spo2 in our study. Hence this study merits to continue with higher sample size.

Key Words: Pulse rate, saturation of hemoglobin, Sleep duration

\section{INTRODUCTION}

$\mathrm{E}$ ach one of us has a unique sleep requirement. Our sleep need depends upon genetic and physiological factors and also varies by age, sex, and previous sleep amounts. However, a simple definition of sufficient sleep is a sleep duration that is followed by a spontaneous awakening and leaves one feeling refreshed and alert for the day.[5] The National Sleep Foundation suggests that adults need 7--9 hours of sleep per night; Individuals who experience long or short sleep durations are more likely to report poor self-rated health than healthy sleepers. [1,2] Although chronic sleep loss is common in today's society, many people are unaware of the potential adverse health effects of habitual sleep restriction. [3] Short sleep duration was more common among adults aged 20--39 years. The relationship between sleep duration, performance and health is important and timely. Between 1959 [6] and 1992 [7] the average amount of sleep reported by middle age individuals decreased by about one hour per night (from 8-9 hours per night to 7-8 hours per night). A study examining the sleep duration from time diaries (records of sleep time and awake time) of full time workers from 1975 to 2006 [8], found a significant increase in the number of individuals who were sleeping less than 6 hours per night. A recent study from the National Health Interview Survey which examined the sleep duration of individuals across several occupations ranging from manufacturing to public administration found that the percent of workers who reported a sleep duration of 6 hours or less per night increased from 24 to $30 \%$ [9] in the last 20 years. These findings probably demonstrate the development of widespread partial sleep deprivation or sleep "restriction" which is most likely related to external environmental or social factor(s) such as the need to work more

\section{Address for correspondence*}

Mukkadan J.K,

Research Director,Little Flower Medical Research Centre, Angamaly,Kerala.

Email:drmukkadan@sify.com than one job or longer work shifts rather than a biologic change in need for sleep.

The important question is the extent to which such changes produce negative consequences for performance, health, and/or quality of life. Participants who are allowed to sleep for only 6 hours per night for 12 nights responded as slowly as other participants did after one night without any sleep at all [10]. Additional changes associated with similar total sleep loss include decreased short-term memory, Short sleep duration is associated with increased CHD (coronary heart disease) mortality and morbidity in both males and females. [4] Several research studies have shown that sleep restriction to about 4 hours per night on 1 - 2 nights has significant effects on normal individuals. Studies have shown an increased heart rate and blood pressure [11], increased inflammation as measured by C-reactive protein (a marker of inflammation which can be measured in the blood and which has been proposed as a risk factor for coronary artery disease-[12], impaired glucose tolerance (which can be a prelude to the development of diabetes-[13], and increased hunger/appetite (which could promote obesity -[14]. In addition, information obtained from questionnaires in large sample groups has also shown statistical associations between chronically reduced sleep duration and increased risk of hypertension (particularly in women) [15,16]; diabetes[17]; and weight gain[18-20].

The present study was undertaken with an objective to observe the effect of sleep duration on spo 2 and pulse rate and to create awareness among the general population to improve the quality of life.

\section{MATERIALSAND METHODS}

\section{Subjects}

The present study has been performed at Little Flower Medical Research Centre, Angamaly, Kerala, India. A total of two hundred and twenty two healthy male and female college 
students, with mean age $18.55 \pm 0.94$ were participated voluntarily in the medical camp comprising 110 males and 112 females.

The purpose and procedure of the study were explained to each subject. Written informed consent was taken from all the participants. Study protocol was approved by Institutional Ethics Committee of Little Flower Medical Research Centre, Angamaly.

\section{Materials}

Pulse oximetry is a non-invasive method allowing the monitoring of the saturation of hemoglobin and pulse rate. The oximeter uses oximetry to measure functional oxygen saturation in blood. Pulse oximeter works by applying the sensor to a pulsating arteriolar vascular bed, such as a finger or toe. The sensor contains dual light source and a photonic detector.Bone, tissue, pigmentation, and venous vessels normally absorb a constant amount of light over time. The arteriolar bed normally pulsates and absorbs variable amounts of light during the pulsations. The ratio of light absorbed is translated into a measurement of functional oxygen saturation $(\mathrm{SpO} 2)$. Because a measurement of $\mathrm{SpO} 2$ is depend upon light from the sensor, excessive ambient light can interfere with this measurement.

\section{Pulse oximetry is based on two principles}

Oxyhaemoglobin and deoxyhaemoglobin differ in their absorption of red and infrared light.

The volume of arterial blood in tissue (hence light absorption by the blood) changes during the pulse.

The oximeter determines $\mathrm{SpO} 2$ by passing red and infrared light into an arteriolar bed and measuring changes in light absorption during pulsatile cycle.Red and infrared low voltage light emitting diodes (LED) serves as light sources; a photonic diode serves as the photodetector.Because oxyhaemoglobin and deoxyhaemoglobin differ in light absorption, the amount of red and infrared light absorbed by blood is related to hemoglobin oxygen saturation.

To identify the oxygen saturation of arterial hemoglobin, the oximeter uses the pulsatile nature of arterial flow. During systole, a new pulse of arterial blood enters the vascular bed, and blood volume and light absorption increase. During diastole, blood volume and light absorption reach their lowest point. The oximeter bases its $\mathrm{SpO} 2$ measurements on the difference between maximum and minimum absorption (measurements at systole and diastole).by doing so, it focuses on light absorption by pulsatile arterial blood, eliminating the effects of non - pulsatile absorption by tissue, bone and venous blood.

\section{Data collection}

The preset study was conducted at 9 am in the morning for the convenience of students. Two investigators of our study recorded Spo2 and pulse rate by using pulse oximeter from the students at the same time. The participants were grouped into two groups, those who sleep more than seven hours and those who sleep for less than seven hours and their spo2 pulse rate were compared.

\section{Data analysis}

The analysis of data was done by SPSS 20.0. Independent sample t test is used for data analysis.
Table: 1 Mean values of $\mathrm{Spo} 2$ and pulse rate in college students.

\begin{tabular}{|c|c|c|c|}
\hline \multirow[b]{2}{*}{ Variable } & \multicolumn{2}{|c|}{ Sle eping time } & \multirow[b]{2}{*}{$\begin{array}{c}\mathrm{p} \\
\text { value }\end{array}$} \\
\hline & $\begin{array}{l}\text { More than } \\
\text { or equal to } \\
7 \text { hours } \\
\end{array}$ & $\begin{array}{l}\text { Less than } 7 \\
\text { hours }\end{array}$ & \\
\hline $\mathrm{SPO}_{2}$ & $98.47 \pm 1.75$ & $98.18 \pm 0.60$ & 0.277 \\
\hline Pluse rate & $91.34 \pm 7.82$ & $89.98 \pm 7.47$ & 0.372 \\
\hline
\end{tabular}

Table: 2 Mean values of $\mathrm{Spo} 2$ and pulse rate in male college students.

\begin{tabular}{|c|c|c|c|}
\hline \multirow[b]{2}{*}{ Variable } & \multicolumn{2}{|c|}{ Sle eping time - Males } & \multirow[b]{2}{*}{$\begin{array}{l}\mathrm{p} \\
\text { value }\end{array}$} \\
\hline & $\begin{array}{l}\text { More than or } \\
\text { equal to } 7 \\
\text { hours }\end{array}$ & $\begin{array}{l}\text { Less than } 7 \\
\text { hours }\end{array}$ & \\
\hline $\mathrm{SPo} 2$ & $98.22 \pm 2.10$ & $98.16 \pm 0.45$ & 0.864 \\
\hline Pluse rat & $90.89 \pm 7.39$ & $89.66 \pm 7.39$ & 0.594 \\
\hline
\end{tabular}

Table:3 Mean values of Spo2 and pulse rate in female college students.

\begin{tabular}{|c|c|c|c|}
\hline \multirow[b]{2}{*}{ Variable } & \multicolumn{2}{|c|}{ Sle eping time - F emale } & \multirow[b]{2}{*}{$\begin{array}{l}\mathrm{p} \\
\text { value }\end{array}$} \\
\hline & $\begin{array}{l}\text { More than } \\
\text { or equal to } \\
7 \text { hours }\end{array}$ & $\begin{array}{l}\text { Less than } 7 \\
\text { hours }\end{array}$ & \\
\hline $\mathrm{SPo} 2$ & $98.6 \pm 1.56$ & $98.24 \pm 0.83$ & 0.371 \\
\hline $\begin{array}{l}\text { Pluse } \\
\text { rate }\end{array}$ & $91.57 \pm 7.56$ & $90.59 \pm 7.79$ & 0.665 \\
\hline
\end{tabular}

\section{RESULTS}

The analysis of data is presented in Table:1. Mean spo2 in the students who sleep more than seven hours is $98.47 \pm 1.75$ and in those who sleep less than seven hours is $98.18 \pm 0.60$, indicates that spo 2 is equal in both the groups. Mean pulse rate in the students who sleep more than seven hours is $91.34 \pm 7.82$ and in those who sleep less than seven hours is $89.98 \pm 7.47$, indicates that pulse rate is slightly lower in the students who sleep less than seven hours. However this is not statistically significant ( $\mathrm{P}$ value 0.372 ).

Mean spo2 in male students who sleep more than seven hours is $98.22 \pm 2.10$ and in those who sleep less than seven hours is $98.16 \pm 0.45$, indicates that spo 2 is almost equal in both the groups.Mean pulse rate in the students who sleep more than seven hours is $90.89 \pm 7.39$ and in those who sleep less than seven hours is $89.66 \pm 7.39$, indicates that pulse rate is slightly lower in the students who sleep less than seven hours. However this is not statistically significant (Pvalue 0.594).

Mean spo2 in male students who sleep more than seven hours is $98.6 \pm 1.56$ and in those who sleep less than seven hours is $98.24 \pm 0.83$, indicates that spo 2 is almost equal in both the groups. Mean pulse rate in the students who sleep more than seven hours is $91.57 \pm 7.56$ and in those who sleep less than seven hours is $90.59 \pm 7.79$, indicates that pulse rate is slightly lower in the students who sleep less than seven hours. However this is not statistically significant (Pvalue 0.665 ).

\section{DISCUSSION}

Self-reported sleep disorders are associated with greater variability in home $\mathrm{BP} / \mathrm{HR}$ and both have cardiovascular prognostic value. 21 A short sleep duration is expected to elevate blood pressure the next morning. Days with sleep duration of less than 7 hours showed higher morning systolic blood pressure and heart rate compared with days with sleep duration between 7 and 8 hours, but no difference was found in diastolic blood pressure. Moreover, although the difference in morning systolic blood pressure had disappeared at night, the difference in heart rate was 
still maintained.22

Insomnia symptoms and shorter objective sleep duration are associated with lower HRV and higher HR and $\mathrm{LF} / \mathrm{HF}$ ratio, indicative of disturbance of cardiac autonomic modulation (CAM) towards more sympathetic and lower parasympathetic modulation.23 Sleep duration may be associated to low mean oxygen saturation in OSA patients. 24 In the present study we have observed lower pulse rate is in the students who sleep less than seven hours. The same is observed when compared with in males and within females. We haven't observed significant difference in spo 2 .

\section{CONCLUSION}

Our study suggests that Pulse rate is slightly lower in the students whose sleep duration is less. No significant change is observed in spo 2 in our study. Hence this study merits to continue with higher sample size

\section{REFERENCES}

1. http://www.news-medical.net/news/20131014/Sleepduration-negatively-impacts-on-self-rated-health.aspx.

2. National Sleep Foundation. How much sleep do we really need? Washington, DC: National Sleep Foundation; 2010. Available at http://www.sleepfoundation.org/article/howsleep-works/how-much-sleep-do-we-really-need

3. Alvarez GG, Ayas NT. The impact of daily sleep duration on health. A review of literature. Prog Cardiovasc Nurs. 2004 Spring;19(2):56-9.

4. Chandola T, Ferrie JE, Perski A, Akbaraly T, Marmot MG. Effect of short sleep duration on coronary heart disease risk is greatest among those with sleep disturbance; A prospective study from the Whitehall II cohort. Sleep. 2010 Jun; 33(6):739-44.

5. http://www.sleepfoundation.org/article/white-papers/howmuch-sleep-do-adults-need.

6. Kripke D, Simons R, Garfinkel L, Hammond E. Short and long sleep and sleeping pills: is increased mortality associated? Arch Gen Psychiat. 1979;36:103-16.7. Bliw is e DL, King AC, Harris RB, Haskell WL. Prevalence of selfreported poor sleep in a healthy population aged 50-65. Soc Sci Med. 1992;34(1):49-55.

8. Knutson KL, Van Cauter E, Rathouz PJ, DeLeire T, Lauderdale DS. Trends in the prevalence of short sleepers in the USA: 1975-2006. Sleep. 2010;33: 37-45.

9. Luckhaupt SE, SangWoo T, Calvert GM. The prevalence of short sleep duriation by industry and occupation in the national health interview survey. Sleep. 2010; 33:149-59.20

10. Van Dongen HPA, Maislin G, Mullington JM, Dinges DF. The cumulative cost of additional wakefulness: doseresponse effects on neurobehavioral functions and sleep physiology from chronic sleep restriction and total sleep deprivation. Sleep. 2003;26:117-26.

11. Tochikubo O, Ikeda A, Miyajima E, Ishii M. Effects of insufficient sleep on blood pressure monitored by a new multibiomedical recorder. Hypertension. 1996;27(6):131824.

12.Meier-Ewert HK, Ridker PM, Rifai N, Regan MM, Price NJ, Dinges DF, et al. Effect of sleep loss on C-reactive protein, an inflammatory marker of cardiovascular risk. J Am CollCardiol.2004;43: 678-83.

13. Spiegel K, Leproult R, Van Cauter E. Impact of sleep debt on metabolic and endocrine function. Lancet. 1999; 354: 143539.

14. Spiegel K, Tasali E, Penev P, Van Cauter E. Sleep curtailment in healthy young men is associated with decreased leptin levels, elevated ghrelin levels, and increased hunger and appetite. Ann Intern Med. 2004;141: 846-50.

15. Knutson KL, Van Cauter E, Rathouz PJ, Yan LL, Hulley SB, Liu K, et al. Association between sleep and blood pressure in midlife: the CARDIA sleep study. Arch Intern Med. 2009Jun8;169(11):1055-61.

16. Stranges S, Dorn JM, Cappuccio FP, Donahue RP, Rafalson LB, Hovey KM, et al. A population-based study of reduced sleep duration and hypertension: the strongest association may be in premenopausal women. J Hypertens. 2010;28(5):896902.

17. Cappuccio FP, D'Elia L, Strazzullo P, Miller MA. Quantity and quality of sleep and incidence of type 2 diabetes: a systematic review and meta-analysis. Diabetes Care. 2010 Feb;33(2):414-20.

18. Patel SR, Hu FB. Short Sleep Duration and Weight Gain: A Systematic Review. Obesity (SilverSpring).2008;16(3):64353.

19. Watson NF, Buchwald D, Vitiello MV, Noonan C, Goldberg j. A twin study of sleep duration and body mass index. J ClinSleepMed. 2010;6:11-7.

20. Hairston KG, Bryer-Ash M, Norris JM, Haffner S, Bowden DW, Wagenknecht LE. Sleep duration and five-year abdominal fat accumulation in a minority cohort: The IRAS family study. Sleep. 2010;33: 289-95.

21. Johansson JK, Kronholm E, Jula AM. Variability in home measured blood pressure and heart rate; associations with self reported insomnia and sleep duration. J Hypertens. 2011 Oct;29(10):1897-905.

22. Kawabe H, Saito I. Does sleep duration in daily life affect morning home blood pressure? Evaluation in Japanese population. Clin Exp Hypertens. 2008 Apr; 30(3):183-90.

23. Sol M. Rodríguez-Colón1, Fan He1, Michele L. Shaffer1, Xian Li1, Alexandros N. Vgontzas2, Edward O. Bixler2, Rongling Wu1, Duanping Liao. Insomnia symptoms and sleep duration are associated with impaired cardiac autonomic modulation in children. Neuroscience \& Medicine, 2011, 2, 288-294.

24. Risso TT, Poyares D, Rizzi CF, Pulz C, Guilleminault C, Tufik $\mathrm{S}$, de Paola AA, Cintra F. The impact of sleep duration in obstructive sleep apnoea patients. Sleep Breath. 2013 May;17(2):837-43. 